COVID-19

\title{
COVID-19 in the tonsillectomised population
}

\section{COVID-19 nella popolazione tonsillectomizzata}

\begin{abstract}
Vincenzo Capriotti ${ }^{*}$, Francesco Mattioli2*, Francesco Guida1 ${ }^{1}$, Alberto Vito Marcuzzo ${ }^{1}$, Alfredo Lo Manto², Andrea Martone ${ }^{2}$, Giulia Molinari², Cristoforo Fabbris ${ }^{3}$, Anna Menegaldo³, Leonardo Calvanese ${ }^{3}$, Gino Latini ${ }^{4}$, Cristina Cingolani ${ }^{4}$, Paolo Gradoni ${ }^{4}$, Francesca Boscolo Nata ${ }^{5}$, Clelia De Sisti ${ }^{6}$, Vittorio Selle ${ }^{6}$, Giordano Leone ${ }^{7}$, Pietro Indelicato ${ }^{7}$, Francesco Pilolli ${ }^{8}$, Niccolò Mevio ${ }^{8}$, Luca Roncoroni ${ }^{8}$, Simona Papi ${ }^{9}$, Marianna Meschiari' ${ }^{10}$, Riccardo Tominz ${ }^{11}$, Luca D'Ascanio ${ }^{4}$, Alberto Dragonetti ${ }^{8}$, Lucio Torelli'12, Loris Trenti13, Giacomo Spinato ${ }^{3}$, Paolo Boscolo-Rizzo ${ }^{3}$, Mario Bussi ${ }^{6}$, Andrea Cossarizza ${ }^{14}$, Livio Presutti², Giancarlo Tirelli ${ }^{1}$

${ }^{1}$ Otorhinolaryngology-Head and Neck Surgery Department, Azienda Sanitaria Universitaria Giuliano Isontina, Trieste, Italy; ${ }^{2}$ Otorhinolaryngology-Head and Neck Surgery Department, University Hospital of Modena, Italy; ${ }^{3}$ ENT Clinic and Regional Center for Head and Neck Cancer, University of Padova Faculty of Medicine and Surgery, Department of Neurosciences, Treviso Regional Hospital, Treviso, Italy; ${ }^{4}$ Institute of Otorhinolaryngology, Department of Head and Neck Surgery, Santa Croce Hospital AORMN, Fano (PU), Italy; ${ }^{5}$ Otorhinolaryngology Unit, Monselice Hospital, Ospedali Riuniti Padova Sud "Madre Teresa di Calcutta", Monselice (PD), Italy; ${ }^{6}$ Hygiene and Public Health Unit, Department of Prevention, Hospital of Chioggia, AULSS 3 Serenissima, Chioggia (VE), Italy; ${ }^{7}$ Department of Otorhinolaryngology, San Raffaele Hospital, Milano, Italy; ${ }^{8}$ Department of Otorhinolaryngology, ASST Grande Ospedale Metropolitano Niguarda, Milano, Italy; ${ }^{9}$ Department of Surgery and Clinical Specialties, University of Modena and Reggio Emilia, Modena, Italy; ${ }^{10}$ Department of Infectious Diseases, Azienda Ospedaliero-Universitaria Policlinico of Modena, University of Modena and Reggio Emilia Faculty of Medicine and Surgery, Modena, Italy; ${ }^{11}$ Department of Prevention, Azienda Sanitaria Universitaria Giuliano Isontina, Trieste, Italy; ${ }^{12}$ Department of Medical, Surgical and Health Sciences, University of Trieste, Italy; ${ }^{13}$ Department of General and Digestive Surgery, Colorectal Unit, Bellvitge University Hospital, Barcelona, Spain; ${ }^{14}$ Department of Biomedical Sciences, University of Modena and Reggio Emilia, Modena, Italy
\end{abstract}

*V. Capriotti and F. Mattioli contributed equally to this work.

\section{SUMMARY}

Objective. Interactions between SARS-CoV-2 and pharyngeal associated lymphoid tissue are thought to influence the manifestations of COVID-19. We aimed to determine whether a previous history of tonsillectomy, as a surrogate indicator of a dysfunctional pharyngeal associated lymphoid tissue, could predict the presentation and course of COVID-19.

Methods. Multicentric cross-sectional observational study involving seven hospitals in Northern and Central Italy. Data on the clinical course and signs and symptoms of the infection were collected from 779 adults who tested positive for SARS-CoV-2, and analysed in relation to previous tonsillectomy, together with demographic and anamnestic data.

Results. Patients with previous tonsillectomy showed a greater risk of fever, temperature higher than $39^{\circ} \mathrm{C}$, chills and malaise. No significant differences in hospital admissions were found.

Conclusions. A previous history of tonsillectomy, as a surrogate indicator of immunological dysfunction of the pharyngeal associated lymphoid tissue, could predict a more intense systemic manifestation of COVID-19. These results could provide a simple clinical marker to discriminate suspected carriers and to delineate more precise prognostic models.

KEY WORDS: COVID-19, SARS-CoV-2, coronavirus, tonsils, tonsillectomy

\section{RIASSUNTO}

Obiettivo. Si ritiene che le manifestazioni dell'infezione da SARS-CoV-2 siano influenzate dalle interazioni tra il virus e il tessuto linfatico associato alla faringe. Obiettivo di questo studio è determinare se una pregressa tonsillectomia, come indicatore surrogato di disfunzione immunologica faringea, possa predire la presentazione e il decorso della COVID-19. Metodi. Studio multicentrico trasversale osservazionale coinvolgente 7 centri italiani. Sono stati raccolti i dati su decorso, segni e sintomi dell'infezione da 779 adulti positivi al SARS$\mathrm{CoV}-2$, e analizzati in relazione a pregressa tonsillectomia, dati demografici e anamnestici. Risultati. I pazienti con pregressa tonsillectomia hanno un maggior rischio di sviluppare febbre, raggiungere temperature oltre $i 39^{\circ} \mathrm{C}$, brividi e malessere generalizzato. Non si riscontrano differenze nel tasso di ospedalizzazione.
Received: January 31, 2021

Accepted: March 1, 2021

Published online: May 6, 2021

Correspondence

Vincenzo Capriotti

Otorhinolaryngology-Head and Neck Surgery Department, Azienda Sanitaria Universitaria Giuliano Isontina, strada di Fiume 447, 34149 Trieste, Italy Tel. +39040 3994736. Fax+390403994180

E-mail: vince.capriotti@gmail.com

Funding

None.

\section{Conflict of interest}

The Authors declare no conflict of interest.

How to cite this article: Capriotti V, Mattioli F, Guida F, et al. COVID-19 in the tonsillectomised population. Acta Otorhinolaryngol Ital 2021;41:197-205. https://doi. org/10.14639/0392-100X-N1436

( ) Società Italiana di Otorinolaringoiatria e Chirurgia Cervico-Facciale

\section{(c) (1) $\$()$}

This is an open access article distributed in accordance with the CC-BY-NC-ND (Creative Commons Attribution-NonCommercial-NoDerivatives 4.0 International) license. The article can be used by giving appropriate credit and mentioning the license, but only for non-commercial purposes and only in the original version. For further information: https:// creativecommons.org/licenses/by-nc-nd/4.0/deed.en 
Conclusioni. Il dato anamnestico di pregressa tonsillectomia, come indicatore di disfunzione immunologica faringea, può predire una manifestazione sistemica più intensa nei pazienti affetti da COVID-19. Questi risultati possono fornire un marker clinico semplice per discriminare sospetti portatori del virus e delineare modelli prognostici più accurati.

PAROLE CHIAVE: COVID-19, SARS-CoV-2, coronavirus, tonsille, tonsillectomia

\section{Introduction}

Coronavirus disease 2019 (COVID-19), caused by the severe acute respiratory syndrome coronavirus 2 (SARSCoV-2), has shown a wide variety of manifestations, ranging from asymptomatic infection to critical respiratory failure ${ }^{1,2}$. Fever, cough, shortness of breath and sudden onset of smell and taste deficiency are frequently reported, alongside gastrointestinal disturbances and non-specific complaints such as myalgia and malaise ${ }^{1}$. Various risk factors have been debated to influence symptom severity and prognosis, such as sex, coexisting chronic disorders and tobacco use; however, the interindividual variability and susceptibility are not fully understood ${ }^{3,4}$.

The role of the pharyngeal microenvironment in the transmission, modulation, and clinical progression of SARS$\mathrm{CoV}-2$ infection has been receiving growing attention ${ }^{5}$. SARS-CoV-2 is known to enter the host mucosa via the angiotensin converting enzyme $2^{6}$, which it uses to colonise the upper airway tract in addition to other target organs ${ }^{7}$. The pharyngeal surfaces of the upper airways are characterised by secondary lymphoid organs and mucosal-associated lymphoid tissue (MALT), which form a morphofunctional immunologic unit known as "Waldeyer's ring". Waldeyer's ring is a key structure in stimulating locoregional immune response and tolerance towards infective stimuli. In this lymphoid tissue, foreign antigens are processed and presented to naïve lymphocytes through a complex network involving dendritic, T-helper and B-cells, eventually forming high affinity colonies that differentiate in activated plasma cells and memory cells. This process leads to specific IgA production, which can be found all along the upper airway tract mucosa and secretions; on the other hand, the memory B-cells generated migrate to other lymphoid organs, such as the spleen and local and distant lymph nodes ${ }^{8}$.

An intrinsic incapability to elicit and regulate an appropriate immune response is thought to be a key element in the pathogenesis of recurrent tonsillitis; the resulting chronic inflammatory state further jeopardises the mutual interaction between the locoregional immune cells and with foreign pathogens, leading to a vicious cycle that ends with failure to form an effective barrier against infective agents ${ }^{9}$. Tonsillectomy represents one of the most frequently performed operations by otolaryngologists and surgeons, and constitutes the mainstay treatment for chronic or recurrent tonsillitis that do not benefit from medical therapy alone ${ }^{10}$. It has long been debated if tonsillectomy might interfere with host immune response and susceptibility to airborne infections. The first studies appeared in the early 1970s, when Ogra showed a reduced level of IgA in nasopharyngeal secretions and a diminished local immune response to oral poliovirus vaccine in children who had undergone adeno-tonsillectomy ${ }^{11}$. Since then, several reports have been published, with non-univocal conclusions: if removal of the palatine tonsils alone does not seem to considerably influence humoral and cellular systemic immunity ${ }^{12}$, their importance in both promoting and effecting the local inflammatory response and production of antibody-secreting cells is better outlined, with the latter spreading throughout the upper airway mucosa and memory cells migrating to regional and distant lymph nodes and secondary lymphoid organs ${ }^{13}$. This key role decreases with age, but residual activity has been found in patients older than 80 years; chronic and recurrent inflammation are crucial in accelerating the decay of immune function ${ }^{8}$.

If the role of pharyngeal microenvironment in COVID-19 pathophysiology and course is of great research interest, its usefulness in daily practice requires clinical markers that could provide information on its status. In the hypothesis that a previous tonsillectomy could reflect a locoregional chronic inflammatory state as a result of an impaired immunological Waldeyer's ring activity, we wanted to assess its possible role as a predictor of interindividual variability in host response to SARS-CoV-2 infection.

\section{Materials and methods}

\section{Study design}

We conducted this multicentric observational cross-sectional study at 7 centres from Northern and Central Italy, areas with a high prevalence of confirmed cases at the time of the study (University Hospital of Trieste; University Hospital of Modena; Treviso Regional Hospital; IRCCS San Raffaele Scientific Institute, Milan; Niguarda Hospital, Milan; Hospital of Chioggia; Hospital of Fano) ${ }^{14}$.

The study was approved by the Ethics Committee of the Friuli Venezia Giulia Region on June $16^{\text {th }}$, 2020 (CEUR2020-Os-156), and informed consent was obtained verbally for telephone interviews. The authors received no funding for the study. 


\section{Patients}

Adults ( $\geq 18$ years) assessed at the participant hospitals between February $25^{\text {th }}$ and May $20^{\text {th }}, 2020$, were included if they tested positive for SARS-CoV-2 RNA by polymerase chain reaction on nasopharyngeal and throat swabs performed according to the World Health Organization recommendation ${ }^{15}$. Criteria for exclusion were a diagnosis of cognitive impairment reported by the patient or a caregiver, and inability to answer one or more questions in the questionnaire.

\section{Data collection}

Data were collected from clinical charts compiled during hospitalisation, during evaluation in the emergency room, at the moment of the pharyngeal swab testing and updated with subsequent telephonic monitoring, which was active during the state of emergency for the treatedat-home patients and performed by trained medical personnel. Any missing information was eventually filled in by trained medical personnel who recalled the patients, assessing missing demographic and anamnestic data and possible common signs and symptoms of COVID-19 that were not reported or updated in the charts. The examined items were arbitrarily chosen based on the most frequent COVID-19-associated comorbidities, signs and symptoms, as reported by the literature at the time of the study design. Patients were considered affected by a coexisting disorder if they had been previously diagnosed and if (one of the following): i) required or had required pharmacological therapy; ii) led to a hospital admission; iii) treated with surgery or with chemotherapy, radiotherapy, biological therapy, or other oncological therapies.

Signs and symptoms were classified as COVID-19-related if they appeared de novo or as a worsening of a chronic symptom within a period of 14 days before or after the positive result of the microbiological test. Those who did not develop new signs, symptoms, or worsening of a chronic symptom within this period were classed as "asymptomatic". Interviews were conducted at least 20 days after the microbiological test in order to reduce the risk of false asymptomatic cases in pre-symptomatic patients.

\section{Outcomes}

The primary outcome was to determine differences in the prevalence of the investigated signs and symptoms among patients who had undergone tonsillectomy and patients who had not. Risk to develop a sign or a symptom according to previous history of tonsillectomy was assessed in the multivariate analysis, together with patient characteristics.

Secondary outcome was risk estimation of hospital admis- sion according to previous history of tonsillectomy. Patient characteristics hypothesised to influence outcomes, together with previous tonsillectomy, were included in multivariate analysis.

\section{Sample size calculation}

Sample size was determined considering patients with a previous tonsillectomy as the case group and fever as the event, assuming that fever is highly common among patients with COVID-19 and, being a sign rather than a symptom, is less prone to patient subjective interpretation. Given a population with a supposed prevalence of $25 \%$ of tonsillectomies, hypothesising a prevalence of fever of $70 \%$ in the group who had undergone tonsillectomy and of $60 \%$ in the group who had not, it was necessary to enroll 585 patients, with $\alpha=5 \%$ and power $(1-b)=95 \%$.

\section{Statistical analysis}

Continuous variables were expressed as means and standard deviation or medians and interquartile ranges (IQR), according to data distribution determined with the ShapiroWilk test. Categorical variables were summarised as counts and percentages. No imputation was made for missing data. In univariate analysis, Fisher's exact test was performed for categorical variables, whereas the Mann-Whitney U test was performed for continuous variables. Logistic regression was performed in multivariate analysis; results of multivariate analysis are reported as odds ratio (OR) and $95 \%$ confidence interval (95\% CI).

$\mathrm{P}$ values $<0.05$ (two-sided) were considered statistically significant. Statistical analyses were performed using SPSS Version 26 (IBM Corp., Armonk, NY, USA).

\section{Results}

\section{Patients}

We recruited 779 patients. Table I shows the distribution of patient characteristics in detail, overall and in relation to previous tonsillectomy. Median age was $50.0 \pm 20.1$ years, and $54.2 \%$ of patients were female. Active smokers accounted for $10.5 \%$, and former smokers and non-smokers for $21.6 \%$ and $67.9 \%$, respectively. About one-third of the population had at least one comorbidity (38.5\%), with a higher prevalence of chronic cardiovascular disease or hypertension (15.9\%) and obesity (13.9\%).

Tonsillectomy had been performed on $27.3 \%$ of patients. Tonsillectomised patients appeared to be older and with a higher prevalence of associated disorders than the non-tonsillectomised subgroup. No difference in sex distribution was recorded among the two groups. 
Table I. Clinical characteristics of study patients.

\begin{tabular}{|c|c|c|c|c|}
\hline \multirow[t]{2}{*}{ Characteristic } & \multirow{2}{*}{$\begin{array}{l}\text { All patients } \\
\qquad \mathrm{n}=779\end{array}$} & \multicolumn{2}{|c|}{ Tonsillectomy } & \multirow[b]{2}{*}{$\mathrm{p}$} \\
\hline & & $\begin{array}{c}\text { Yes } \\
n=213\end{array}$ & $\begin{array}{c}\text { No } \\
\mathrm{n}=566\end{array}$ & \\
\hline Age - median (IQR) & $50.0(20.1)$ & $55.2(14.0)$ & $48.0(19.2)$ & $<0.001^{* \cdots}$ \\
\hline \multicolumn{5}{|l|}{ Sex } \\
\hline Male sex & $357(45.8)$ & $106(49.8)$ & $251(44.3)$ & 0.20 \\
\hline Female sex & $422(54.2)$ & $107(50.2)$ & $315(55.7)$ & \\
\hline \multicolumn{5}{|l|}{ Smoking history } \\
\hline Current & $82(10.5)$ & $21(9.9)$ & $61(10.8)$ & 0.79 \\
\hline Former & $168(21.6)$ & $47(22.1)$ & $121(21.4)$ & 0.85 \\
\hline Never & $529(67.9)$ & $145(68.1)$ & $384(67.8)$ & $>0.99$ \\
\hline Current alcohol consumption & $267(34.3)$ & 77 (36.2) & $190(33.6)$ & 0.50 \\
\hline Presence of any allergy & $271(34.8)$ & $77(36.2)$ & $194(34.3)$ & 0.67 \\
\hline BMI - median (IQR) & $25.0(5.3)$ & $25.1(5.6)$ & $24.9(5.2)$ & 0.13 \\
\hline Any coexisting disorder & $300(38.5)$ & $106(49.8)$ & $194(34.3)$ & $<0.001^{* \cdots}$ \\
\hline Obesity & $108(13.9)$ & $36(16.9)$ & $72(12.7)$ & 0.13 \\
\hline Chronic pneumopathy & $36(4.6)$ & $13(6.1)$ & $23(4.1)$ & 0.25 \\
\hline Chronic cardiovascular disease or hypertension & $124(15.9)$ & $50(23.5)$ & $74(13.1)$ & $0.001^{* * * *}$ \\
\hline Diabetes & $44(5.6)$ & $21(9.9)$ & $23(4.1)$ & $0.003^{* *}$ \\
\hline Immunodeficiency & $3(0.4)$ & $1(0.5)$ & $2(0.4)$ & $>0.99$ \\
\hline Autoimmune disease & $60(7.7)$ & $18(8.5)$ & $42(7.4)$ & 0.65 \\
\hline Chronic renal disease & $11(1.4)$ & $5(2.3)$ & $6(1.1)$ & 0.18 \\
\hline Hepatopathy & $24(3.1)$ & $10(4.7)$ & $14(2.5)$ & 0.16 \\
\hline Cancer (current or previous) & $21(2.7)$ & $6(2.8)$ & $15(2.7)$ & $>0.99$ \\
\hline
\end{tabular}

Column percentages are reported in brackets for categorical variables. $p$-values refer to the univariate analysis (Fisher's exact test, Mann-Whitney's U test). IQR: interquartile range. BMl: body mass index. ${ }^{~}{ }^{*}=p<0.05 .{ }^{{ }^{* *}}=p<0.01 .{ }^{*{ }^{* *}}=p<0.001$.

\section{Tonsillectomy and SARS-CoV-2 infection}

The distribution of the examined signs and symptoms according to previous tonsillectomy and related univariate analysis are summarised in Table II. Tonsillectomised patients showed a significantly higher prevalence of fever, temperature greater than $39^{\circ} \mathrm{C}$ and shortness of breath, with a lower rate of nasal congestion and myalgia compared to patients who did not undergo tonsillectomy.

Table III summarises the results of multivariate analysis, showing the signs and symptoms at augmented risk to be developed in case of previous tonsillectomy. Patients with a previous history of tonsillectomy showed greater risk to report fever and to reach temperatures higher than $39^{\circ} \mathrm{C}$. An increased risk for chills and malaise was also observed. The association with nasal congestion was lost.

Tonsillectomised patients did not show an increased risk to develop the other investigated signs and symptoms: cough (OR 1.06, 95\% CI 0.69-1.63, p = 0.78), shortness of breath (OR 1.35, 95\% CI 0.86-2.11, p = 0.19, confusion (OR 1.58, 95\% CI 0.87-2.90, $\mathrm{p}=0.14$ ), rhinorrhoea (OR 0.99, 95\% CI $0.58-1.70, \mathrm{p}=0.98)$, nasal congestion (OR $0.68,95 \% \mathrm{CI}$
0.41-1.13, $\mathrm{p}=0.14)$, sore throat $(\mathrm{OR} 1.60,95 \%$ CI 0.98-2.62, $\mathrm{p}=0.06$ ), myalgia (OR $0.93,95 \%$ CI $0.61-1.43, \mathrm{p}=0.76$ ), dizziness (OR 1.12, 95\% CI 0.57-2.21, $\mathrm{p}=0.75$ ), headache (OR 1.12, 95\% CI 0.73-1.72, $\mathrm{p}=0.60$ ), nausea (OR 0.62, 95\% CI 0.33-1.14, $\mathrm{p}=0.12$ ), diarrhoea (OR 1.16, 95\% CI $0.75-1.80, \mathrm{p}=0.51)$. Odds to have an asymptomatic course did not differ between tonsillectomised and non-tonsillectomised patients (OR 1.26, 95\% CI 0.53-3.00, p = 0.60).

\section{Tonsillectomy and risk of hospitalisation}

While previous tonsillectomy was more prevalent among patients admitted to hospital, tonsillectomised patients did not show an increased risk for admission at the multivariate analysis (Tab. IV).

\section{Discussion}

In our study, we wanted to explore the possibility that a previous tonsillectomy, as an indicator of chronic tonsillitis and possibly of immunological dysfunction of the Waldeyer's ring, could reflect the underlying characteristic of the 
Table II. Distribution of COVID-19-related signs and symptoms.

\begin{tabular}{|c|c|c|c|c|}
\hline \multirow[t]{2}{*}{ Signs and symptoms } & \multirow{2}{*}{$\begin{array}{c}\text { All patients } \\
\mathrm{n}=779\end{array}$} & \multicolumn{2}{|c|}{ Tonsillectomy } & \multirow[b]{2}{*}{$\mathrm{p}$} \\
\hline & & $\begin{array}{c}\text { Yes } \\
n=213\end{array}$ & $\begin{array}{c}\text { No } \\
n=566\end{array}$ & \\
\hline Asymptomatic & $46(5.9)$ & $13(6.1)$ & $33(5.8)$ & 0.87 \\
\hline Fever & $508(65.2)$ & 156 (73.2) & $352(62.2)$ & $0.004^{* *}$ \\
\hline $\mathrm{T}>39^{\circ} \mathrm{C}$ & $82(10.5)$ & 36 (16.9) & $46(8.1)$ & $0.001^{* *}$ \\
\hline Cough & $411(52.8)$ & $113(53.1)$ & $298(52.7)$ & 0.94 \\
\hline Shortness of breath & $239(30.7)$ & 80 (37.6) & $159(28.1)$ & $0.01^{*}$ \\
\hline Chills & $255(32.7)$ & $76(35.7)$ & $179(31.6)$ & 0.30 \\
\hline Malaise & $423(54.3)$ & $124(58.2)$ & $299(52.8)$ & 0.20 \\
\hline Confusion & $89(11.4)$ & $30(14.1)$ & 59 (10.4) & 0.17 \\
\hline Rhinorrhoea & $150(19.3)$ & $37(17.4)$ & $113(20.0)$ & 0.48 \\
\hline Nasal congestion & $193(24.8)$ & $40(18.8)$ & $153(27.0)$ & $0.02^{*}$ \\
\hline Sore throat & $180(23.1)$ & $53(24.9)$ & $127(22.4)$ & 0.51 \\
\hline Myalgia & $385(49.4)$ & $92(43.2)$ & $293(51.8)$ & $0.04^{*}$ \\
\hline Dizziness & 78 (10.0) & $19(8.9)$ & 59 (10.4) & 0.59 \\
\hline Headache & $343(44.0)$ & $87(40.8)$ & $256(45.2)$ & 0.29 \\
\hline Nausea & $126(16.2)$ & $29(13.6)$ & $97(17.1)$ & 0.28 \\
\hline Diarrhoea & $260(33.4)$ & 77 (36.2) & $183(32.3)$ & 0.35 \\
\hline Smell disturbance & $446(57.3)$ & $113(53.1)$ & $333(58.8)$ & 0.17 \\
\hline Taste disturbance & $446(57.3)$ & $113(53.1)$ & $333(58.8)$ & 0.17 \\
\hline
\end{tabular}

Column percentages are reported in brackets for categorical variables. $p$-values refer to the univariate analysis (Fisher's exact test). ${ }^{*}=p<0.05 .{ }^{~}{ }^{*}=p<0.01 .{ }^{* *+}=p<0.001$.

patient pharyngeal MALT and related COVID-19 manifestations.

In our population, tonsillectomised patients showed an increased risk of developing fever and temperatures higher than $39^{\circ} \mathrm{C}$, along with malaise and chills. It is plausible that malaise and chills were consequences of the fever and its intensity, reflecting a more intense systemic involvement. Patients with previous history of tonsillectomy were older and with more coexisting disorders than those who did not receive the operation. However, even accounting for these possible confounding factors in the multivariate logistic regression, tonsillectomised patients still showed a greater risk to express a more intense systemic response to the virus. In the multivariate analysis, $\mathrm{p}$-values associated with augmented risk to develop fever and temperatures higher than $39^{\circ} \mathrm{C}$ were far below the value of 0.05 set for significance $(\mathrm{p}=0.003$ and $\mathrm{p}<0.001$, respectively), bypassing the possible over-powering effect of our large sample and giving strength to our hypothesis.

As mentioned above, tonsillectomy itself is probably an indicator rather than the cause of a decreased Waldeyer's ring immune function; its activity of defense and inflammatory regulation is furtherly worsened by chronic infections that eventually lead to a vicious cycle and to surgical removal ${ }^{8}$. Significant differences have been demonstrated between frequently infected palatine tonsils compared to healthy controls, such as a different composition of the antigenpresenting cell (APC) population, a reduced capability in regulating the inflammatory response and decreased $\operatorname{Ig} \mathrm{A}$ and IgM production ${ }^{13}$.

Frequently infected tonsils show an abnormal distribution of activated dendritic cells (DCs), the most efficient APC, which appear superficially concentrated on the lympho-epithelium in addition to the interfollicular T-cell areas: this suggests an increased production of inflammatory mediators and chemotactic dysregulation ${ }^{16-18}$. DCs also mediate B-/T-cell interaction, which results in the selection of specific activated B-cells, memory B-cells and antiinflammatory T-cell-derived cytokines such as IL-10 ${ }^{19}$ : impairment of the role of DC could undermine these essential immune functions in patients with chronic tonsillitis ${ }^{13}$.

Moreover, tonsils subjected to chronic inflammation show a reduced production of anti-inflammatory cytokines and a lowered tolerance to viral infections compared to isolated hyperplasia. In a study by Mikola et al., tonsillar mRNA expression of IL-37, a fundamental inhibitor of innate immunity and inflammatory cytokines, appeared to be diminished in the chronic tonsillitis group when adjusted for age ${ }^{20}$. Additionally, B-regulatory cells suppress effector 
Table III. COVID-19-related signs and symptoms affected by history of previous tonsillectomy.

\begin{tabular}{|c|c|c|c|c|c|c|c|c|}
\hline \multirow{2}{*}{$\begin{array}{l}\text { Characteristic } \\
\text { Tonsillectomy }\end{array}$} & \multicolumn{2}{|c|}{ Fever } & \multicolumn{2}{|c|}{$\mathrm{T}>39^{\circ} \mathrm{C}$} & \multicolumn{2}{|c|}{ Chills } & \multicolumn{2}{|c|}{ Malaise } \\
\hline & $\begin{array}{c}2.06 \\
(1.27-3.33)\end{array}$ & $0.003^{\star \star}$ & $\begin{array}{c}3.68 \\
(2.04-6.63)\end{array}$ & $<0.001^{\star \star \star}$ & $\begin{array}{c}1.71 \\
(1.10-2.65)\end{array}$ & $0.02^{*}$ & $\begin{array}{c}1.71 \\
(1.10-2.65)\end{array}$ & $0.02^{*}$ \\
\hline Age & $\begin{array}{c}1.00 \\
(0.99-1.01)\end{array}$ & 0.68 & $\begin{array}{c}1.00 \\
(0.98-1.02)\end{array}$ & 0.64 & $\begin{array}{c}0.99 \\
(0.98-1.01)\end{array}$ & 0.83 & $\begin{array}{c}0.99 \\
(0.98-1.01)\end{array}$ & 0.35 \\
\hline Female sex & $\begin{array}{c}0.47 \\
(0.34-0.67)\end{array}$ & $<0.001^{\star \star *}$ & $\begin{array}{c}0.52 \\
(0.30-0.89)\end{array}$ & $0.02^{\star}$ & $\begin{array}{c}1.29 \\
(0.93-1.78)\end{array}$ & 0.80 & $\begin{array}{c}1.29 \\
(0.93-1.78)\end{array}$ & 0.13 \\
\hline Smoking history & & $0.001^{\star *}$ & & 0.72 & & $0.007^{*}$ & & $0.006^{\star}$ \\
\hline Current & $\begin{array}{c}0.39 \\
(0.24-0.63)\end{array}$ & $<0.001^{\star \star \star}$ & $\begin{array}{c}0.92 \\
(0.39-2.17)\end{array}$ & 0.86 & $\begin{array}{c}0.46 \\
(0.28-0.76)\end{array}$ & $0.002^{\star *}$ & $\begin{array}{c}0.46 \\
(0.28-0.76)\end{array}$ & $0.002^{* *}$ \\
\hline Former & $\begin{array}{c}0.96 \\
(0.65-1.43)\end{array}$ & 0.85 & $\begin{array}{c}1.24 \\
(0.70-2.20)\end{array}$ & 0.46 & $\begin{array}{c}1.07 \\
(0.74-1.55)\end{array}$ & 0.73 & $\begin{array}{c}1.07 \\
(0.74-1.55)\end{array}$ & 0.73 \\
\hline Alcohol consumption & $\begin{array}{c}0.93 \\
(0.65-1.43)\end{array}$ & 0.69 & $\begin{array}{c}0.87 \\
(0.51-1.49)\end{array}$ & 0.62 & $\begin{array}{c}1.70 \\
(1.22-2.38)\end{array}$ & 0.72 & $\begin{array}{c}1.70 \\
(1.22-2.38)\end{array}$ & $0.002^{*}$ \\
\hline Allergies & $\begin{array}{c}1.20 \\
(0.87-1.67)\end{array}$ & 0.27 & $\begin{array}{c}1.22 \\
(0.73-2.03)\end{array}$ & 0.44 & $\begin{array}{c}1.06 \\
(0.78-1.45)\end{array}$ & 0.55 & $\begin{array}{c}1.06 \\
(0.78-1.45)\end{array}$ & 0.71 \\
\hline Body mass index & $\begin{array}{c}1.00 \\
(0.95-1.05)\end{array}$ & 0.92 & $\begin{array}{c}1.01 \\
(0.93-1.10)\end{array}$ & 0.79 & $\begin{array}{c}0.99 \\
(0.94-1.04)\end{array}$ & 0.85 & $\begin{array}{c}0.99 \\
(0.94-1.04)\end{array}$ & 0.68 \\
\hline Any coexisting disorder & $\begin{array}{c}0.82 \\
(0.45-1.51)\end{array}$ & 0.53 & $\begin{array}{c}1.53 \\
(0.68-3.43)\end{array}$ & 0.30 & $\begin{array}{c}0.95 \\
(0.54-1.68)\end{array}$ & 0.58 & $\begin{array}{c}0.95 \\
(0.54-1.68)\end{array}$ & 0.86 \\
\hline Obesity & $\begin{array}{c}1.29 \\
(0.61-2.71)\end{array}$ & 0.51 & $\begin{array}{c}1.30 \\
(0.48-3.55)\end{array}$ & 0.61 & $\begin{array}{c}1.69 \\
(0.84-3.41)\end{array}$ & 0.96 & $\begin{array}{c}1.69 \\
(0.84-3.41)\end{array}$ & 0.14 \\
\hline Pneumopathy & $\begin{array}{c}0.84 \\
(0.38-1.85)\end{array}$ & 0.66 & $\begin{array}{c}0.83 \\
(0.26-2.64)\end{array}$ & 0.75 & $\begin{array}{c}0.64 \\
(0.29-1.38)\end{array}$ & 0.39 & $\begin{array}{c}0.64 \\
(0.29-1.38)\end{array}$ & 0.25 \\
\hline $\begin{array}{l}\text { Cardiovascular disease or } \\
\text { hypertension }\end{array}$ & $\begin{array}{c}1.35 \\
(0.74-2.44)\end{array}$ & 0.32 & $\begin{array}{c}0.97 \\
(0.46-2.03)\end{array}$ & 0.94 & $\begin{array}{c}0.98 \\
(0.57-1.69)\end{array}$ & 0.60 & $\begin{array}{c}0.98 \\
(0.57-1.69)\end{array}$ & 0.94 \\
\hline Diabetes & $\begin{array}{c}1.10 \\
(0.49-2.46)\end{array}$ & 0.82 & $\begin{array}{c}1.49 \\
(0.60-3.68)\end{array}$ & 0.39 & $\begin{array}{c}2.48 \\
(1.13-5.45)\end{array}$ & 0.61 & $\begin{array}{c}2.48 \\
(1.13-5.45)\end{array}$ & $0.02^{*}$ \\
\hline Immunodeficiency & $\begin{array}{c}0.60 \\
(0.04-8.37)\end{array}$ & 0.70 & $\begin{array}{c}0.00 \\
(0.00-.)\end{array}$ & $>0.99$ & $\begin{array}{c}1.16 \\
(0.08-16.74)\end{array}$ & 0.60 & $\begin{array}{c}1.16 \\
(0.08-16.74)\end{array}$ & 0.91 \\
\hline Autoimmune disease & $\begin{array}{c}1.43 \\
(0.70-2.93)\end{array}$ & 0.33 & $\begin{array}{c}0.98 \\
(0.37-2.59)\end{array}$ & 0.97 & $\begin{array}{c}0.87 \\
(0.45-1.69)\end{array}$ & 0.49 & $\begin{array}{c}0.87 \\
(0.45-1.69)\end{array}$ & 0.68 \\
\hline Renal disease & $\begin{array}{c}1.25 \\
(0.27-5.78)\end{array}$ & 0.78 & $\begin{array}{c}0.65 \\
(0.07-5.80)\end{array}$ & 0.70 & $\begin{array}{c}2.36 \\
(0.45-12.52)\end{array}$ & 0.19 & $\begin{array}{c}2.36 \\
(0.45-12.52)\end{array}$ & 0.31 \\
\hline Hepatopathy & $\begin{array}{c}3.52 \\
(0.99-12.55)\end{array}$ & 0.05 & $\begin{array}{c}2.15 \\
(0.75-6.18)\end{array}$ & 0.16 & $\begin{array}{c}1.24 \\
(0.49-3.12)\end{array}$ & 0.19 & $\begin{array}{c}1.24 \\
(0.49-3.12)\end{array}$ & 0.65 \\
\hline Cancer (current or previous) & $\begin{array}{c}1.22 \\
(0.44-3.39)\end{array}$ & 0.71 & $\begin{array}{c}1.57 \\
(0.40-6.28)\end{array}$ & 0.52 & $\begin{array}{c}2.03 \\
(0.73-5.63)\end{array}$ & 0.94 & $\begin{array}{c}2.03 \\
(0.73-5.63)\end{array}$ & 0.18 \\
\hline
\end{tabular}

Results of the multivariate logistic regression. Odds ratio (95\% confidence interval) and $p$-values for each variable are reported. ${ }^{*}=p<0.05 .{ }^{* \star}=p<0.01 .{ }^{* \star *}=p<0.001$.

T-cells and other lymphocytes via production of IL-10, IL35 and TGF- $\beta$, and they are involved in supporting immunological tolerance. These cells are distributed among all human lymphoid tissues, including the palatine and nasopharyngeal tonsils ${ }^{21}$.

Finally, the impaired secretion of $\operatorname{IgM}$ and $\operatorname{IgA}$ finds its molecular counterpart in a reduced cytoplasmatic expression of the J-chain, a peptide implied in the formation of the cited polymeric immunoglobulins, among youngsters with recurrent tonsillitis ${ }^{22}$. In the possibility of routine application of a rapid salivary SARS-CoV-2 screening test, it might be necessary to take into account the role of the tonsils in mediating the production of secretive antibodies and local clearance of the virus ${ }^{23}$.

All these features, together with the components of the innate immunity hosted by pharyngeal MALT, are involved in the response against viruses and have a role in the interindividual variability of the manifestation and transmission of COVID- $19^{5}$, as our findings appear to support.

For what concerns the severity and clinical course of the disease, assuming hospital admission as a surrogate indicator of severity, no significant differences emerged between tonsillectomised and non-tonsillectomised patients. This finding, representing the secondary outcome of our 
Table IV. Distribution of patient characteristics according to clinical course and risk of hospital admission.

\begin{tabular}{|c|c|c|c|c|c|}
\hline \multirow[t]{2}{*}{ Characteristic } & \multirow{2}{*}{$\begin{array}{l}\text { Treated at home } \\
\begin{array}{c}n(\%)= \\
668(85.8)\end{array}\end{array}$} & \multirow{2}{*}{$\begin{array}{c}\text { Admitted to hospital } \\
n(\%)= \\
111(14.2)\end{array}$} & \multirow{2}{*}{$\begin{array}{l}\text { Univariate analysis } \\
\qquad p\end{array}$} & \multicolumn{2}{|c|}{ Multivariate analysis } \\
\hline & & & & OR $(95 \% \mathrm{Cl})$ & $\mathrm{p}$ \\
\hline Age & $48.0(19.0)$ & $62.3(19.1)$ & $<0.001^{\star \star *}$ & $1.07(1.05-1.09)$ & $<0.001^{* * *}$ \\
\hline \multicolumn{6}{|l|}{ Sex } \\
\hline Male & $283(42.4)$ & $74(66.7)$ & $<0.001^{* * *}$ & $2.33(1.37-3.98)$ & $0.002^{* *}$ \\
\hline Female & $385(57.6)$ & 37 (33.3) & & Ref & - \\
\hline Smoking history & & & & - & $0.01^{*}$ \\
\hline Current & $79(11.8)$ & $3(2.7)$ & $0.002^{* * *}$ & $0.26(0.07-0.92)$ & $0.04^{*}$ \\
\hline Former & $126(18.9)$ & $42(37.8)$ & $<0.001^{* * *+}$ & $1.62(0.97-2.69)$ & 0.07 \\
\hline Never & $463(69.3)$ & $66(59.5)$ & 0.05 & Ref & - \\
\hline Current alcohol consumption & $208(31.1)$ & 59 (53.2) & $<0.001^{*+*}$ & $1.37(0.83-2.24)$ & 0.22 \\
\hline Presence of any allergy & $243(36.4)$ & $28(25.2)$ & $0.02^{*}$ & $0.68(0.40-1.14)$ & 0.15 \\
\hline $\mathrm{BMI}$ & $24.7(5.2)$ & $26.8(5.2)$ & $<0.001^{*+*}$ & $1.01(0.93-1.10)$ & 0.78 \\
\hline Any coexisting disorder & $232(34.7)$ & $68(61.3)$ & $<0.001^{* * * *}$ & $2.43(1.12-5.29)$ & $0.03^{*}$ \\
\hline Obesity & $85(12.7)$ & $23(20.7)$ & $0.04^{\star}$ & $1.07(0.40-2.87)$ & 0.89 \\
\hline Chronic pneumopathy & $29(4.3)$ & $7(6.3)$ & 0.33 & $1.10(0.38-3.18)$ & 0.86 \\
\hline $\begin{array}{l}\text { Chronic cardiovascular disease or } \\
\text { hypertension }\end{array}$ & $96(14.4)$ & $28(25.2)$ & $0.007^{* *}$ & $0.42(0.21-0.85)$ & $0.02^{*}$ \\
\hline Diabetes & $33(4.9)$ & $11(9.9)$ & 0.05 & $0.47(0.19-1.20)$ & 0.12 \\
\hline Immunodeficiency & $3(0.4)$ & $0(0.0 \%)$ & 1.00 & $0.00(0.00-)$. & $>0.99$ \\
\hline Autoimmune disease & $51(7.6)$ & $9(8.1)$ & 0.85 & $1.03(0.40-2.61)$ & 0.96 \\
\hline Chronic renal disease & $6(0.9)$ & $5(4.5)$ & $0.01^{*}$ & $4.99(1.05-23.83)$ & $0.04^{*}$ \\
\hline Hepatopathy & $18(2.7)$ & $6(5.4)$ & 0.14 & $0.79(0.25-2.54)$ & 0.69 \\
\hline Cancer (current or previous) & $12(1.8)$ & $9(8.1)$ & $0.001^{* *}$ & $1.50(0.48-4.71)$ & 0.49 \\
\hline Tonsillectomy & $171(25.6)$ & $42(37.8)$ & $0.01^{*}$ & $1.38(0.75-2.53)$ & 0.30 \\
\hline
\end{tabular}

Counts (column percentages) are reported in brackets for categorical variables, medians (interquartile range) are reported for continuous variables. Results of the univariate (Fisher's exact test, Mann-Whitney's U test) and multivariate (logistic regression) analysis are reported, with related p-values. BMI: Body Mass Index. OR: odds ratio. 95\% Cl: 95\% confidence

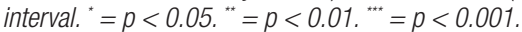

work, may have been partially biased by the impossibility to retrieve accurate data from those who died, as well as the lack of other surrogate indicators such as hospitalisation time, complication rate and the small percentage of asymptomatic subjects. A more inclusive cohort accounting for all the above-mentioned biases and possible indicators of severity and complications may be necessary to specifically clarify the possible role of Waldeyer's ring status on the global severity and clinical course of the disease.

Our results seem to corroborate a potentially independent role of pharyngeal-associated lymphoid organs in the host response to SARS-CoV-2 infection. The fundamental importance of these organs in patrolling the upper airways against SARS-CoV-2 and other infective agents has been widely recognised ${ }^{5}$. The higher prevalence of systemic signs and symptoms in the tonsillectomised patients in our cohort can be explained hypothesising that intrinsic impair- ment of the pharyngeal lymphoid tissues led to both chronic tonsillitis and tonsillectomy in the past, and now the same dysfunction could be responsible for an altered response to SARS-CoV-2. An uncontrolled inflammatory reaction to the virus, mediated by a dysfunctional Waldeyer's ring, could have led to fever, higher temperatures and associated symptoms. From this perspective, previous tonsillectomy as an indicator of an impaired immunological activity of pharyngeal MALT could be regarded as a predictor of an altered host response to SARS-CoV-2 infection. Vice-versa, people with a functional Waldeyer's ring could develop more subtle and less intense symptoms, possibly leading to lack of identification of viral carriers.

As tonsillectomy is frequently performed and has a high prevalence in general population, this anamnestic information may take on potential relevance in the context of the COVID-19 pandemic ${ }^{10}$. If these findings are confirmed by further studies, investigating history of previous tonsil- 
lectomy could help physicians to characterise the clinical manifestations in patients with suspected SARS-CoV-2 infection: knowing that non-tonsillectomised patients might show less symptoms and pass unnoticed, this could be a relevant information to correctly refer for screening tests wherever these are administered on the basis of the reported symptomatology ${ }^{24}$.

The main limitation of this study is represented by the absence of deceased patients in our cohort, which may have affected the analysis of disease severity according to the variables investigated. This was unavoidable because of the impossibility to retrieve complete information about previous operations, coexisting disorders and COVID19-related symptoms. However, it was deemed acceptable at the time of the study design given the small percentage of deaths in relation to the total number of cases in Italy during the recruitment phase, probably with low effects on the outcomes ${ }^{25}$.

Another limitation may be the self-reported nature of the information on coexisting disorders. We tried to limit inaccuracies by relying on objective data such as pharmacological history and diagnosis made during hospital admission. The main strength of this work is the completeness of the data analysed, prospective collection of information and lack of assumptions for missing data.

\section{Conclusions}

According to our results, patients with SARS-CoV-2 infection and previous tonsillectomy might be more likely to develop a more intense and systemic response, with fever, higher temperatures, chills and malaise. This may reflect subtle differences in the immunological response to the virus caused by impaired pharyngeal MALT functionality. Although non-conclusive, these findings may shed new light on the pathophysiology of COVID-19 and support current evidence on the role of the pharyngeal microenvironment on the disease course. If confirmed, these results could help discriminate suspected SARS-CoV-2 carriers, providing indications for the screening test knowing the higher risk of a subtler manifestation in non-tonsillectomised patients, and potentially delineating more precise prognostic models.

\section{Acknowledgements}

The authors wish to thank Itala Mary Ann Brancaleone, MA, RSA Dip TEFLA, teacher of Medical English at the University of Trieste, for her support in editing the manuscript.

\section{References}

1 Lechien JR, Chiesa-Estomba CM, Place S, et al. Clinical and epidemiological characteristics of 1420 European patients with mild-tomoderate coronavirus disease 2019. J Intern Med 2020;288:335-344. https://doi.org/10.1111/joim.13089

2 Guan W, Ni Z, Hu Y, et al. Clinical characteristics of Coronavirus disease 2019 in China. N Engl J Med 2020;382:1708-1720. https:// doi.org/10.1056/NEJMoa2002032

3 Giannouchos TV, Sussman RA, Mier JM, et al. Characteristics and risk factors for COVID-19 diagnosis and adverse outcomes in Mexico: an analysis of 89,756 laboratory-confirmed COVID-19 cases. Eur Respir J 2020:2002144. https://doi.org/10.1183/13993003.021442020

4 Pascarella G, Strumia A, Piliego C, et al. COVID-19 diagnosis and management: a comprehensive review. J Intern Med 2020;288:192206. https://doi.org/10.1111/joim.13091

5 Gallo O, Locatello LG, Mazzoni A, et al. The central role of the nasal microenvironment in the transmission, modulation, and clinical progression of SARS-CoV-2 infection. Mucosal Immunol 2021;14:305316. https://doi.org/10.1038/s41385-020-00359-2

6 Ni W, Yang X, Yang D, et al. Role of angiotensin-converting enzyme 2 (ACE2) in COVID-19. Crit Care 2020;24:422. https://doi. org/10.1186/s13054-020-03120-0

7 Zou L, Ruan F, Huang M, et al. SARS-CoV-2 Viral load in upper respiratory specimens of infected patients. N Engl J Med 2020;382:11771179. https://doi.org/10.1056/NEJMc2001737

8 Brandtzaeg P. Immunology of tonsils and adenoids: everything the ENT surgeon needs to know. Int Congr Ser 2003;1254:89-99. https:// doi.org/10.1016/S0531-5131(03)00964-6

9 Brandtzaeg P. Immunocompetent cells of the upper airway: functions in normal and diseased mucosa. Eur Arch Otorhinolaryngol 1995;252:S8-S21. https://doi.org/10.1007/BF02484429

10 Hall MJ, Schwartzman A, Zhang J, et al. Ambulatory surgery data from hospitals and ambulatory surgery centers: United States, 2010. Natl Health Stat Report 2017;(102):1-15.

11 Ogra PL. Effect of tonsillectomy and adenoidectomy on nasopharyngeal antibody response to poliovirus. N Engl J Med 1971;284:59-64. https://doi.org/10.1056/NEJM197101142840201

12 Altwairqi RG, Aljuaid SM, Alqahtani AS. Effect of tonsillectomy on humeral and cellular immunity: a systematic review of published studies from 2009 to 2019. Eur Arch Otorhinolaryngol 2020;277:1-7. https://doi.org/10.1007/s00405-019-05672-6

13 van Kempen MJP, Rijkers GT, van Cauwenberge PB. The immune response in adenoids and tonsils. Int Arch Allergy Immunol 2000;122:819. https://doi.org/10.1159/000024354

14 Mannelli G, Ralli M, Bonali M, et al. Impact of COVID-19 pandemic on Italian Otolaryngology Units: a nationwide study. Acta Otorhinolaryngol Ital 2020;40:325-331. https://doi. org/10.14639/0392-100X-N0832

15 World Health Organization. Country \& technical guidance - coronavirus disease (COVID-19). Accessed August 4, 2020. https://www. who.int/emergencies/diseases/novel-coronavirus-2019/technicalguidance

16 Björck P, Flores-Romo L, Liu Y-J. Human interdigitating dendritic cells directly stimulate CD40-activated naive B cells. Eur J Immunol 1997;27:1266-1274. https://doi.org/10.1002/eji.1830270531

17 Bani D, Gallo O, Fini-Storchi O. Intraepithelial lymphocyte subpopulations and dendritic accessory cells in normal and hypertrophic adenoids. Laryngoscope 1994;104:869-873. https://doi. org/10.1288/00005537-199407000-00017

18 Brodsky L, Frankel S, Gorfien J, et al. The role of dendritic cells in 
the development of chronic tonsillar disease in children. Acta OtoLaryngol Suppl 1996;523:98-100.

19 Rousset F, Garcia E, Banchereau J. Cytokine-induced proliferation and immunoglobulin production of human B lymphocytes triggered through their CD40 antigen. J Exp Med 1991;173:705-710. https:// doi.org/10.1084/jem.173.3.705

20 Mikola E, Elenius V, Saarinen M, et al. Tonsillar cytokine expression between patients with tonsillar hypertrophy and recurrent tonsillitis. Clin Transl Allergy 2018;8:22. https://doi.org/10.1186/s13601-0180205-z

21 Mauri C, Menon M. Human regulatory B cells in health and disease: therapeutic potential. J Clin Invest 2017;127:772-779. https://doi. org/10.1172/JCI85113
22 Korsrud FR, Brandtzaeg P. Influence of tonsillar disease on the expression of $\mathrm{j}$ chain by immunoglobulin-producing cells in human palatine and nasopharyngeal tonsils. Scand J Immunol 1981;13:281-287. https://doi.org/10.1111/j.1365-3083.1981.tb00136.x

23 Wyllie AL, Fournier J, Casanovas-Massana A, et al. Saliva or nasopharyngeal swab specimens for detection of SARS-CoV-2. N Engl J Med 2020;383:1283-1286. https://doi.org/10.1056/NEJMc2016359

24 European Centre for Disease Prevention and Control. Diagnostic testing and screening for SARS-CoV-2. https://www.ecdc.europa.eu/ en/covid-19/latest-evidence/diagnostic-testing. Accessed August 4, 2020.

25 Istituto Superiore di Sanità. EpiCentro. Coronavirus. https://www.epicentro.iss.it/coronavirus/bollettino/Bollettino-sorveglianza-integrataCOVID-19_8-settembre-2020.pdf . Accessed September 14, 2020. 